\title{
Adaptasi alat ukur kesuksesan karier subjektif
}

\author{
Tri Muji Ingarianti ${ }^{1,4}$, Fendy Suhariadi $^{2}$, dan Fajrianthi ${ }^{3}$
}

\begin{abstract}
Subjective career success is an attitude regarding an individual's achievement and satisfaction with their career resulting from a personal evaluation of their career experience. Subjective career success has eight dimensions: recognition, quality work, meaningful work, influence, authenticity, personal life, growth and development, and satisfaction. Subjective Career Success Inventory - SCSI (Subjective Career Success Questionnaire) has 24 items. The use of instruments at different cultural backgrounds requires an adaptation process so that the measurement results are valid and reliable, but until now, there has been no research on the adaptation of subjective career success measurement tools in Indonesia. The purpose of this study is to obtain a standardized subjective career success measurement tool. The adaptation process was carried out using the International Test Commission reference in 2016. Based on the results of the CFA analysis of the LISREL 8.8 program, it can be concluded that according to theory, subjective career success models have a good fit model. This means that the zero hypotheses that state the subjective career success model of the goodness of fit are acceptable. This explains that the resulting model can describe actual conditions and can be used to measure subjective career success.
\end{abstract}

\section{Keywords}

Adaptation, subjective career success, SCSI, measurement

\section{Pendahuluan}

Saat ini, topik kesuksesan karier masih menjadi topik yang sangat diminati bagi para peneliti karier dari berbagai sudut pandang (Akkermans \& Kubasch, 2017; Gunz \& Heslin, 2005; Ng et al., 2005; Seibert et al., 2013). Kesuksesan karier merupakan konstruk yang menarik karena mengungkap tentang standar internal dan harapan seseorang serta menjadi kunci bagi motivasi, kepuasan, komitmen, bahkan kinerja (Abele \& Spurk, 2009; Dries et al., 2009; Heslin, 2003).

Kesuksesan karier sering didefinisikan sebagai akumulasi hasil kerja dan psikologis yang dihasilkan dari pengalaman kerja seseorang (Judge et al., 1995). Di satu sisi, kesuksesan karier tercermin dari kesuksesan yang dapat diamati, seperti tingkat manajerial, jumlah promosi, gaji, perkembangan gaji, dan sebagainya (Dries et al., 2009; $\mathrm{Ng} \&$ Feldman, 2010). Di sisi lain, kesuksesan karier juga dapat didefinisikan sebagai kesuksesan 'subjektif', seperti evaluasi subjektif individu pada berbagai aspek karier mereka (Greenhaus et al., 1990). Pada penelitian terdahulu, kesuksesan karier lebih banyak dioperasionalkan menggunakan pengukuran-pengukuran objektif (Gunz \& Heslin, 2005). Namun dalam beberapa tahun belakangan, ada perhatian mulai bergeser sehingga saat ini pengukuran subjektif sudah banyak digunakan (Spurk et al., 2019).
Pada penelitian-penelitian empiris, kesuksesan karier subjektif biasanya diukur sebagai kepuasan karier yang bersifat unidimensional (Greenhaus et al., 1990; Seibert et al., 2013) atau persepsi kesuksesan karier (perceived career success) (Heslin, 2003; Turban \& Dougherty, 1994). Pengukuran objektif terhadap kesuksesan karier subjektif masih menjadi norma yang sering digunakan hingga saat ini, di mana responden menilai kepuasan mereka berdasarkan kriteria kesuksesan yang disediakan peneliti dan dianggap universal (Gunz \& Heslin, 2005). Beberapa tahun belakangan, terjadi pergeseran dengan dikembangkannya pengukuran yang lebih detail, yang dapat mengakomodasi definisi kesuksesan karier subjektif secara lebih idiosinkratik dan membantu menjawab pertanyaan penelitian yang lebih beragam. Sebagai contoh, di Tiongkok, Zhou et al. (2013) mengembangkan skala multidimensi tentang external compensation (kompensasi eksternal) dan pemenuhan intrinsik (intrinsic fulfillment). Kemudian di AS, Shockley et al. (2016) menerbitkan alat ukur Subjective Career Success (SCS) multidimensi,

1,2,3 Universitas Airlangga ${ }^{4}$ Universitas Muhammadiyah Malang

Korespondensi:

Tri Muji Ingarianti, Fakultas Psikologi, Universitas Airlangga; Universitas Muhammadiyah Malang

Email: Ingarianti@umm.ac.id 
meliputi beberapa dimensi termasuk pertumbuhan dan perkembangan (growth and development), kehidupan pribadi (personal life), dan keaslian (authenticity).

Sejauh ini, Career Satisfaction Scale (CSS) yang dikembangkan oleh (Greenhaus et al., 1990) merupakan alat ukur kesuksesan karier yang paling sering digunakan. Kajian literatur sampai tahun 2016 mengungkap bahwa CSS ini telah digunakan pada 68 studi terpublikasi tentang kesuksesan karier. Studi-studi ini mayoritas mengamati anteseden kepuasan karier, terutama tentang strategi career self-management, sikap karier, kepribadian, dan karakteristik demografis (Spurk et al., 2019). Pada CSS, skor responden pada kelima item (kepuasan karier secara umum, kemajuan terhadap tujuan karier, tingkat penghasilan, kenaikan jabatan, dan perkembangan keterampilan) dirata-rata menjadi satu skor tunggal. Secara keseluruhan alat ukur ini menunjukkan internal consistency (cronbach's alpha) yang tinggi, meskipun satu penelitian menyampaikan bahwa measurement invariance berpotensi menjadi masalah, dan hanya item "general" (yakni, "Saya puas dengan kesuksesan yang saya capai di karier saya") yang menunjukkan properti psikometri yang baik (Hofmans et al., 2008). Namun, skala ini secara umum dianggap sebagai alat ukur SCS unidimensional terbaik yang ada saat ini. Meski demikian, skala ini tidak cocok untuk menjawab pertanyaan-pertanyaan penelitian yang beragam tentang berbagai cara individu menilai seberapa sukses mereka dalam kariernya (Dries et al., 2008).

Istilah "unidimensional" yang di gunakan oleh para peneliti merujuk pada merujuk pada skala yang berdasarkan rata-rata skor responden dari beberapa skor item/faktor untuk mendapatkan satu nilai global. Alat ukur semacam ini memang memiliki kelebihan (robust, efisien, dan mudah diadaptasi oleh peneliti dari luar bidang penelitian karier yang membahas variabel karier), tetapi tidak sesuai untuk menjawab setiap jenis pertanyaan penelitian. Skala multidimensional membuat peneliti dapat menganalisis sejauh mana sebuah faktor memengaruhi kesuksesan karier subjektif individu. Kemampuan ini merepresentasikan pendekatan subjektivist pada kesuksesan karier, sebuah pendekatan yang didukung para peneliti di bidang ini (Gunz \& Heslin, 2005).

Beberapa tahun belakangan, terdapat perkembangan yang beragam mengenai pengukuran kesuksesan karier subjektif yang mempertimbangkan banyak dimensi (Pan \& Zhou, 2015; Shockley et al., 2016; Zhou et al., 2013). Sebagai contoh, Zhou et al. (2013); Pan \& Zhou (2015) mengidentifikasi tiga dimensi luas kesuksesan karier subjektif di Tiongkok, yaitu intrinsic fulfilment, external compensation, dan work-life balance. Selanjutnya, Shockley et al. (2016), berdasarkan sampel di AS, mengemukakan dan memvalidasi skala yang berisikan dimensidimensi berikut: pengakuan (recognition), pekerjaan yang berkualitas (quality work), pengaruh (influence), keaslian (authenticity), kehidupan pribadi (personal life), growth and development, dan kepuasan umum (general satisfaction). Pada latar budaya masing-masing, kedua skala
Tabel 1. Data Demografis Subjek

\begin{tabular}{lc}
\hline Kategori & Frekuensi (N=288) \\
\hline Jenis Kelamin & \\
Laki-laki & 120 \\
Perempuan & 168 \\
Kelompok Pekerja & \\
BUMN & 90 \\
Perusahaan Swasta & 120 \\
Pegawai Pemerintahan & 78 \\
Tingkat Pendidikan & \\
SMA & 82 \\
D3/D4 & 75 \\
S1 & 101 \\
S2 & 30 \\
\hline
\end{tabular}

ini dilaporkan berhasil merefleksikan makna kesuksesan karier bagi populasi lokal. Namun demikian, kedua skala ini mengandung perbedaan-perbedaan mendasar yang akan menjadi masalah jika digunakan untuk perbandingan lintas budaya dan penelitian multisitus. Misalnya, dari wawancara kualitatif di Tiongkok, Zhou et al. (2013) mengungkap kesuksesan berarti menjaga keluarga, sementara di AS, makna kesuksesan ini tidak ditemukan pada penelitian (Shockley et al., 2016). Sebaliknya, data kualitatif di AS mengungkap adanya career calling, yang tidak ditemukan. Di Indonesia, Ingarianti et al. (2021) menemukan bahwa keberhasilan karier subjektif dipandang sebagai membuat perubahan, pembelajaran informal, kepuasan, keseimbangan hidup, pemenuhan tujuan, dan keseimbangan spiritual.

Di Indonesia, sampai saat ini belum ditemukan penelitian yang melakukan adaptasi terhadap alat ukur kesuksesan karier. Peneliti memandang pentingnya melakukan adaptasi terhadap alat ukur kesuksesan karier yang dikembangkan oleh Shockley et al. (2016) sebagai upaya untuk memberikan alternatif skala kesuksesan karier subjektif yang memiliki sifat psikometri yang memuaskan. (Shockley et al., 2016) mengembangkan alat ukur berdasarkan kelemahan-kelemahan yang ditemukan pada pengukuran sebelumnya. Alat ukur yang dikembangkan tersebut dikenal sebagai Subjective Career Success Inventory (SCSI) yang memiliki reliabilitas pada rentang 0.70 hingga 0.97. SCSI memiliki 24 item dan terdiri dari 8 dimensi, meliputi keaslian, pertumbuhan dan perkembangan, pengaruh, makna dari karier, kehidupan personal, kualitas pekerjaan, rekognisi, dan kepuasan karier. Contoh dari item dalam SCSI, yaitu "Supervisor saya mengatakan bahwa saya melakukan pekerjaan dengan baik", "Saya bangga dengan kualitas pekerjaan yang telah saya kerjakan", dan "Pekerjaan yang telah saya lakukan dapat berkontribusi pada masyarakat". 
Tabel 2. Blue Print Skala Kesuksesan Karier Subjektif

\begin{tabular}{lcc}
\hline Dimensi & Nomor item & Jumlah \\
\hline Recognition & $1,2,3$. & 3 item \\
Quality Work & $4,5,6$. & 3 item \\
Meaningful Work & $7,8,9$. & 3 item \\
Influence & $10,11,12$. & 3 item \\
Authenticity & $13,14,15$. & 3 item \\
Personal Life & $16,17,18$. & 3 item \\
Growth and Development & $19,20,21$. & 3 item \\
Satisfaction & $22,23,24$. & 3 item \\
\hline
\end{tabular}

\section{Metode}

\section{Subjek Penelitian}

\section{Variabel dan Instrumen}

Variabel yang dignakan dalam penelitian adalah kesuksesan karier subjekif. Kesuksesan karier subjektif didefinisikan sebagai evaluasi pelaku karir terhadap pengalaman mencapai hasil karir yang bermakna secara pribadi ( $\mathrm{Ng}$ et al., 2005; Seibert et al., 2001; Shockley et al., 2016). Definisi operasional kesuksesan karier subjektif adalah perasaan terkait pencapaian dan kepuasan individu atas karier mereka yang dihasilkan oleh evaluasi pribadi atas pengalaman kariernya. Semakin tinggi skor yang didapatkan menunjukkan semakin tinggi kepuasan karirnya.

Peneliti memilih menggunakan instrumen yang dikembangkan oleh Shockley et al. (2016) karena dianggap lebih tepat untuk mengukur kesuksesan karier subjektif. Alat ukur yang dikembangkan tersebut dikenal sebagai kuesioner kesuksesan karier subjektif (Subjective Career Success Inventory - SCSI) yang memiliki reliabilitas pada rentang 0.70 hingga 0.97 . SCSI memiliki 24 item dan terdiri dari 8 dimensi, meliputi keaslian, pertumbuhan dan perkembangan, pengaruh, makna dari karier, kehidupan personal, kualitas pekerjaan, rekognisi, dan kepuasan karier. Karakteristik SCSI yang multidimensional dianggap lebih rinci dalam menjelaskan pengaruh aspek-aspek tersebut terhadap berbagai perilaku dibandingkan instrumen lainnya. Dimensi-dimensi yang ada pada SCSI dianggap mewakili pemahaman karyawan di Indonesia yang mendefinisikan kesuksesan karier subjektif sebagai making changes, informal learning, gaining satisfaction, achieving life balance, reaching goal achievement, dan attaining spiritual balance (Ingarianti et al., 2021). Skala asli dapat dilihat pada Appedix 1.

\section{Analisa Data}

Pada penelitian ini terbagi menjadi 2 bagian yaitu bagian adaptasi alat ukur dan bagian pengujian confirmatory factor analysis (CFA) untuk pengujian validitas dan reliabilitas. Bagian pertama adalah adaptasi alat ukur. Pedoman dalam proses adaptasi menggunakan International test commission (ITC) Guidelines for test adaptation (International Test Commission, 2016) yang terdiri dari lima tahap, yaitu pre-condition, test development, confirmation, administration dan documentation.

\section{Hasil dan Pembahasan}

Tahap prakondisi (pre-condition) ini diawali dengan meminta ijin pada pengembang alat ukur sesuai dengan variabel penelitian yaitu Subjective Career Success Inventory (Shockley et al., 2016). Sebelum sampai pada tahap meminta ijin untuk adaptasi alat ukur, penulis telah melakukan telaah pada beberapa alat ukur yang sesuai dengan variabel yang ada pada penelitian ini dan memilih alat ukur yang sesuai dengan variable penelitian. SCSI dikembangkan oleh pengembang alat ukur skala asli berdasarkan teori yang mereka bangun sesuai konsep variable penelitian sehingga hal tersebut menjadi pertimbangan penulis untuk memilih alat ukur tersebut. Pada tahap ini, peneliti mendapatkan ijin dari Shockley sebagai pengembang alat ukur tersebut.

Tahap pengembangan alat ukur ini terdapat beberapa tahap (International Test Commission, 2016), yaitu (a) adaptasi dengan mempertimbangkan perbedaan linguistik, psikologis dan budaya melalui pemilihan pakar (expert) dengan keahlian yang relevan, (b) prosedur penilaian yang tepat dipilih untuk memaksimalkan kesesuaian adaptasi alat ukur, (c) melakukan pilot study untuk memberikan bukti kesamaan instruksi, konten alat ukur, cara administrasi dapat dipahami dan memiliki makna yang sama untuk populasi yang dituju, (d) mengumpulkan data uji coba pada alat ukur yang diadaptasi untuk analisis butir, penilaian reliabilitas dan validitas pengukuran.

Penulis memilih penerjemah yang akan terlibat didalam proses forward translation dan back translation serta para ahli yang akan terlibat pada proses adaptasi. Pemilihan berdasarkan pertimbangan latar belakang pendidikan, kemampuan berbahasa Indonesia dan Inggris, pemahaman budaya, dan keahlian dalam pengukuran, serta pengalaman dan pengetahuan tentang psikologi maupun organisasi.

Tahap pertama diawali dengan proses forward translation yaitu menerjemahkan alat ukur dari bahasa asli (Inggris) ke dalam Bahasa Indonesia. Proses ini dilakukan oleh dua orang penerjemah dengan memberikan informasi mengenai tujuan translasi. Penulis memberikan form forward translation untuk mempermudah penerjemah dalam melakukan proses forward translation. Hasil dari proses ini diberikan kepada forward translation reviewer yang bertugas untuk melakukan sintesa pada kedua hasil terjemahan, yang disebut sebagai skala versi forward translation.

Tahap berikutnya melakukan back translation oleh dua orang penerjemah yang memiliki kemampuan bahasa Inggris dan bahasa Indonesia yang baik. Penerjemah tidak melihat alat ukur asli yang digunakan dalam penelitian ini. Penulis memberikan form back translation yang dapat diisi oleh penerjemah. Hasil sintesis dilakukan oleh backward translation reviewer dan menghasilkan skala versi back translation. 
Setelah proses penerjemahan alat ukur selesai, penulis memberikan skala hasil terjemahan (BT12) dan skala versi asli kepada tiga expert reviewer bahasa, disertai dengan surat pengantar. Surat pengantar ini berisi alasan para ahli dipilih karena kemampuan bahasa dan pengetahuan tentang struktur bahasa yang mereka miliki, yaitu belakang pendidikan bahasa Inggris linguistik, dan pernah/sedang tinggal di luar negeri. Ketiga ahli memberikan validasi dengan membandingkan skala versi asli dan skala hasil terjemahan. Validasi hasil terjemahan (validation of translation) dilakukan dengan cara mengisi rating scale pada form penilaian berdasarkan studi Sperber (2004) Komponen yang dinilai berkaitan dengan tingkat perbandingan (comparability) dan kesamaan (similarity) item antara versi asli dengan versi back translate dengan penilaian skala likert dari 1 (sangat dapat dibandingkan/serupa) sampai dengan 7 (sangat tidak dapat dibandingkan/sangat tidak serupa). Comparability adalah tingkat kesamaan bahasa, frase, istilah, kata dan kalimat secara formal. Similarity merujuk pada tingkat kesamaan makna antara dua versi item, meskipun istilah yang digunakan berbeda. Uraian lebih lanjut penulis sajikan pada bagian validitas dan reliabilitas naskah ini.

Versi pre-final pada pilot studi dilakukan pada 20 orang karyawan dari berbagai latar belakang perusahaan, yang dengan sukarela terlibat pada proses ini. Penulis memberikan form alat ukur dengan disertai kolom komentar supaya karyawan dapat memberikan respon atau masukan terkait butir item yang dimaksud. Secara umum karyawan menyampaikan bahwa alat ukur cukup dapat dipahami baik dari segi instruksi maupun kalimatnya. Beberapa masukan berhubungan dengan tata tulis, seperti menambahkan kata "saya' pada item supaya lebih jelas, penggunaan kata "pegawai atau karyawan”. Masukan yang berkaitan dengan instruksi, seperti menuliskan koreksi bila salah menjawab menjadi pertimbangan penulis untuk digunakan pada saat pengambilan data penelitian.

Uji coba skala dilakukan pada 300 karyawan dari sektor usaha yang bervariasi. Pengambilan data dilakukan secara online. Berdasarkan 300 data, penulis melakukan pengecekan dan tersisa 288 data yang dapat digunakan sebagai data uji coba alat ukur. Hal ini disebabkan oleh beberapa hal, yaitu pengisian ganda (4 orang), isian tidak lengkap (3 orang), masa kerja kurang dari 5 tahun (4), subjek tidak mengijinkan data digunakan untuk publikasi (1 orang).

Pada penghitungan validitas skala kesuksesan karier subyektif diperoleh 5 hasil utama. Yang pertama, adaptasi alat ukur membutuhkan penilaian comparability - similarity oleh expert reviewer yang bertujuan untuk membandingkan antara pernyataan skala asli dengan hasil penerjemahan kembali ke bahasa asli (back translation). Hal ini dilakukan untuk memastikan bahwa setiap pernyataan back translation dari pernyataan terjemahan memiliki kesamaan makna dan bentuk dengan pernyataan asli. Tujuan dari hal ini adalah untuk menjaga validitas dari instrumen yang digunakan (Sperber, 2004). Comparability
Tabel 3. Hasil Perhitungan Content Validity Index (CVI) dan S-CVI

\begin{tabular}{lcc}
\hline Indikator & I-CVI & S-CVI \\
\hline Relevancy & 1 & 1 \\
Importancy & 1 & 1 \\
Clarity & 1 & 1 \\
\hline
\end{tabular}

pernyataan adalah seberapa kesamaan kata, frasa dan kalimat pada pernyataan bahasa asli dan pernyataan terjemahan back translation. Similiarity adalah seberapa kemungkinan tingkat kesamaan respon yang diberikan subjek antara pernyataan skala asli dan pernyataan skala back translation meskipun kedua pernyataan tersebut memiliki kata-kata yang berbeda (Sperber, 2004).

Berdasarkan penilaian masing-masing butir yang dilakukan oleh setiap ahli, dihitung nilai rata-rata dari setiap butir. Sperber (2004) menyatakan jika nilai ratarata $>3$ ( 7 adalah kesepakatan terburuk dan 1 adalah kesepakatan terbaik) maka item memerlukan peninjauan formal dari terjemahan butir. Lebih lanjur Sperber (2004) menjelaskan bahwa butir yang diterjemahkan ulang mungkin berbeda dari skala versi asli dalam bentuk bahasa dan makna yang disampaikan, namun demikian kesamaan makna lebih diutamakan daripada bentuk. Bentuk dapat sengaja divariasikan untuk menjamin kesamaan makna. Pada skala kesuksesan karier subjektif diperoleh hasil memiliki Range Mean Score Comparability sebesar 1 2,33 dan Range Mean Score Similarity sebesar 1 - 2,66.

Hasil yang kedua, menggunakan penghitungan Content validity index (CVI) dan Content validity index scale (SCVI). Validitas pada pendekatan ini adalah validitas isi, yaitu membuktikan sejauh mana item-item merepresentasikan konstruk yang diukur. Pada skala kesuksesan karier subjektif (24 item) diberikan pada expert reviewer yang memiliki latar belakang berupa keahlian atau pengalaman yang berhubungan dengan pengukuran, maupun bidang industri dan organisasi. Para ahli memberikan rating dengan skala 4 poin pada relevansi (relevancy), kepentingan (importancy) dan kejelasan (clarity) item, yaitu $1=$ tidak relevan, tidak penting, tidak jelas; $2=$ agak relevan, agak penting, agak jelas; $3=$ cukup relevan, cukup penting, cukup jelas; 4= sangat relevan, sangat penting, sangat jelas. Relevansi adalah sejauh mana butir atau item sesuai dengan konstruknya, kepentingan adalah seberapa penting butir bila dikaitkan dengan konstruk dan konteks penelitian, dan kejelasan adalah sejauh mana butir dinilai jelas dan mudah dipahami. Pada penelitian ini, evidence based on test content dilakukan dengan cara menghitung content validity index (CVI) pada alat ukur yang diadaptasi. Polit et al. (2007) menyatakan, nilai CVI dapat dihitung untuk setiap butir pada skala (I-CVI) dan untuk skala keseluruhan (S-CVI). Berdasarkan hasil reviu dari para ahli, penulis membuat skor dikotomi terhadap alat ukur, yaitu skor 1 untuk penilaian 3 dan 4 serta skor 0 untuk penilaian 1 dan 2. 
Tabel 3 menunjukkan bahwa skala kesuksesan karier subjektif (24 item) memiliki nilai CVI = 1 karena keempat reviewer memberikan skor 3 dan 4 untuk semua pernyataan pada keempat skala tersebut. Berdasarkan hasil ini maka nilai S-CVI untuk keempat alat ukur ini adalah 1.

Penghitungan validitas yang ketiga adalah validitas konstruk. Validitas konstruk merupakan tingkat sekumpulan pernyataan atau item-item yang digunakan untuk mengukur, dapat merefleksikan konstruk laten secara teoritis sehingga pengukuran tersebut menjadi akurat (Hair et al., 2014). Beberapa cara untuk melakukan pengukuran validitas konstruk antara lain dengan convergen validity dan discriminant validity. Convergen validity diukur lewat factor loading (FL) pada CFA, average variance extracted (AVE) dan construct reliability (CR). Standar nilai convergent validity dengan melihat nilai FL yaitu $>0,5$ namun nilai $\mathrm{FL}>0,4$ dapat diterima apabila nilai $t$-values signifikan dan jumlah subjek yang digunakan adalah $>200$ (Hair $e t$ al., 2014). Selain itu menurut Hair et al. (2014) standar bagi nilai $\mathrm{AVE}$ adalah $>0,05$ dengan nilai $\mathrm{CR}$ sebesar $>0,7$. Namun demikian, nilai CR antara 0,6 - 0,7 masih dapat diterima sebagai standar validitas konstruk (Hair et al., 2014). Selain itu, tokoh lain menyatakan nilai AVE 0,5 masih dapat diterima asalkan nilai CR berkisar $>0,6$ (Fornell \& Larcker, 1981; Huang, Wang, Wu \& Wang, 2013). Berkaitan dengan uji CFA, Hair et al. (2014) juga menyatakan bahwa jumlah pernyataan minimal pada setiap dimensi adalah 3-4 pernyataan. Selain itu terkait dengan kriteria model fit maka aspek kriteria terkadang tidak semuanya dapat terpenuhi. Meskipun demikian standar kriteria model fit minimal memenuhi 3-4 kriteria maka sebuah model dapat dianggap fit (Hair et al., 2014). Peneliti menggunakan standar penilaian validitas konstruk melalui pengujian FL, CR dan AVE sesuai standar penilaian yang dijelaskan sebelumnya. Selain itu standar penilaian lain berupa kriteria jumlah pernyataan pada setiap dimensi dan kriteria model fit seperti penjelasan di atas juga digunakan untuk penilian modal setiap skala di setiap variable. Adapun penjelasan pengukuran validitas konstruk dan uji CFA akan dijelaskan di bawah ini.

Hasil rangkuman uji CFA di atas menunjukkan bahwa nilai FL pernyataan untuk masing-masing dimensi kesuksesan karier subjektif adalah 0,59 -0,91.

Gambar 1 menunjukkan hasil uji CFA skala kesuksesan karier subjektif dengan nilai fit chi-square $=458,84$; df $=224 ; p$-value $=0,000$ dan RMSEA $=0.060$. Adapun kriteria fit lainnya dapat dilihat pada tabel di bawah ini:

Berdasarkan hasil analisa CFA terlihat bahwa skala kesuksesan karier subjektif ini memenuhi kriteria model fit pada semua kriteria. Nilai CR dan AVE skala subjective career success juga memenuhi syarat validitas konvergen.

Pengukuran yang keempat, validitas diskriminan pada model pengukuran dilakukan pada alat ukur yang memiliki multi konstruk untuk melihat apakah setiap konstruk memang berbeda satu sama lain ketika mengukur suatu variable (Hair et al., 2014). Pengukuran validitas diskriminan, salah satunya bisa dilakukan dengan membandingkan
Tabel 4. Rangkuman Uji CFA Skala Kesuksesan Karier Subjektif

\begin{tabular}{|c|c|c|c|c|c|}
\hline Konstruk & $\begin{array}{c}\text { Nomor } \\
\text { Pernyataan }\end{array}$ & $\begin{array}{l}\text { Factor } \\
\text { Loading }\end{array}$ & $\mathrm{CR}$ & AVE & $\begin{array}{l}\text { Akar } \\
\text { AVE }\end{array}$ \\
\hline \multirow[t]{3}{*}{ Recognition } & r1 & .76 & .83 & .62 & .79 \\
\hline & r2 & .82 & & & \\
\hline & r3 & .78 & & & \\
\hline \multirow[t]{2}{*}{ Quality } & qw1 & .67 & & & \\
\hline & qw2 & .78 & .80 & .58 & .76 \\
\hline Work & qw3 & .82 & & & \\
\hline \multirow[t]{2}{*}{ Meaningful } & mw1 & .73 & & & \\
\hline & mw2 & .77 & .70 & .49 & .70 \\
\hline \multirow[t]{2}{*}{ Work } & mw3 & .59 & & & \\
\hline & $\mathrm{i} 1$ & .79 & & & \\
\hline \multirow[t]{3}{*}{ Influence } & i2 & .83 & .84 & .63 & .79 \\
\hline & i3 & .76 & & & \\
\hline & a1 & .71 & & & \\
\hline \multirow[t]{2}{*}{ Authenticity } & a2 & .64 & .71 & .45 & .67 \\
\hline & a3 & .67 & & & \\
\hline \multirow[t]{2}{*}{ Personal } & pl1 & .77 & & & \\
\hline & pl2 & .91 & .87 & .68 & .82 \\
\hline Life & pl3 & .79 & & & \\
\hline \multirow{2}{*}{ Growth and } & gw1 & .85 & & & \\
\hline & gw2 & .86 & .89 & .72 & .85 \\
\hline \multirow{2}{*}{ Development } & gw3 & .84 & & & \\
\hline & s1 & .67 & & & \\
\hline \multirow[t]{2}{*}{ Satisfaction } & s2 & .91 & .86 & .67 & .82 \\
\hline & s3 & .86 & & & \\
\hline
\end{tabular}

akar average variance extracted (AVE) dengan nilai korelasi kuadrat (R2) antar konstruk. Nilai akar AVE pada sebuah konstruk harus lebih tinggi daripada R2 nilai konstruk tersebut.

Selain itu untuk melihat validitas diskriminan pada penelitian Perugini \& Bagozzi (2001) dengan membandingkan nilai korelasi dengan angka 1 , apabila nilai korelasi lebih kecil dari 1 maka validitas diskriminan tercapai. Pada instrumen penelitian ini, alat ukur yang digunakan memiliki konstruk lebih dari satu.

Perhitungan dengan membandingkan nilai akar AVE dan nilai korelasi kuadrat (R2) dapat dilihat pada tabel 6 .

Tabel 6 menunjukkan bahwa seluruh akar AVE pada setiap dimensi menunjukkan nilai yang lebih tinggi daripada nilai R2 antar konstruk sehingga dapat disimpulkan bahwa skala kesuksesan karier subjektif memang terdiri dari 8 dimensi sesuai dengan pijakan teori pada skala asli (Akbulut, 2016). Selain itu, analisisi diskriminan dapat diketahui dengan cara membandingkan nilai korelasi dengan angka 1, apabila nilai korelasi lebih kecil dari 1 maka validitas diskriminan tercapai (Perugini \& Bagozzi, 2001). Berdasarkan tabel di atas menunjukkan bahwa semua nilai korelasi lebih kecil dari 1 sehingga dapat disimpulkan bahwa skala kesuksesan karier subjektif memenuhi ketercapaian validitas diskriminan.

Hasil yang ketiga adalah reliabilitas harus di uji untuk melihat konsistensi pengukuran observed variable secara bersama-sama terhadap asing-masing konstruknya. Confirmatory factor analysis (CFA) dapat digunakan untuk 
Tabel 5. Model Fit Uji CFA

\begin{tabular}{|c|c|c|c|c|}
\hline Kategori & Kriteria & Nilai & Nilai Acuan & Intepretasi \\
\hline \multirow[t]{3}{*}{ Absolute Fit } & Goodness of fit index (GFI) & .88 & $\begin{array}{l}\mathrm{GFI} \geqslant 0.90 \text { adalah Good Fit } 0.80 \leqslant \mathrm{GFI} \geqslant 0.90 \\
\text { adalah Marginal Fit }\end{array}$ & Marginal Fit \\
\hline & $\begin{array}{l}\text { Root mean square error of } \\
\text { approximation (RMSEA) }\end{array}$ & .06 & $\begin{array}{l}\text { RMSEA } \leqslant 0.08 \text { adalah Good Fit RMSEA } \leqslant 0.05 \\
\text { adalah Close Fit }\end{array}$ & Good Fit \\
\hline & Standarized RMR (SRMR) & .05 & SRMR $\leqslant 0.10$ adalah Good Fit & Good Fit \\
\hline \multirow[t]{2}{*}{ Incremental Fit } & Tucker-Lewis Index (TLI) & .97 & $\begin{array}{l}T L I \geqslant 0.90 \text { adalah Good Fit } 0.80 \leqslant T L I \geqslant 0.90 \text { adalah } \\
\text { Marginal Fit }\end{array}$ & Good Fit \\
\hline & Comparative fit index (CFI) & .98 & $\begin{array}{l}\text { CFII } \geqslant 0.90 \text { adalah Good Fit } 0.80 \leqslant \mathrm{CFI} \geqslant 0.90 \\
\text { adalah Marginal Fit }\end{array}$ & Good Fit \\
\hline
\end{tabular}

Tabel 6. Perbandingan Nilai Akar AVE dan R2 antar Konstruk Skala Kesuksesan Karier Subjektif

\begin{tabular}{|c|c|c|c|c|c|c|c|c|}
\hline & Recognition & $\begin{array}{l}\text { Quality } \\
\text { Work }\end{array}$ & $\begin{array}{l}\text { Meaningful } \\
\text { Work }\end{array}$ & Influence & Authenticity & $\begin{array}{l}\text { Personal } \\
\text { Life }\end{array}$ & $\begin{array}{l}\text { Growth and } \\
\text { Development }\end{array}$ & Satisfaction \\
\hline Recognition & .79 & & & & & & & \\
\hline Quality Work & .48 & .76 & & & & & & \\
\hline $\begin{array}{l}\text { Meaningful } \\
\text { Work }\end{array}$ & .35 & .45 & .70 & & & & & \\
\hline Influence & .46 & .44 & .56 & .79 & & & & \\
\hline Authenticity & .41 & .44 & .55 & .44 & .67 & & & \\
\hline Personal Life & .12 & .17 & .21 & .17 & .28 & .82 & & \\
\hline $\begin{array}{l}\text { Growth and } \\
\text { Development }\end{array}$ & .37 & .29 & .38 & .38 & .58 & .18 & .85 & \\
\hline Satisfaction & .35 & .31 & .52 & .27 & .42 & .19 & .31 & .82 \\
\hline
\end{tabular}

Tabel 7. Rangkuman hasil uji CR dan AVE Kesuksesan Karier Subjektif

\begin{tabular}{lcc}
\hline Konstruk & $\begin{array}{c}\text { Construct } \\
\text { Reliability (CR) }\end{array}$ & $\begin{array}{c}\text { Average Variance } \\
\text { Extracted (AVE) }\end{array}$ \\
\hline Recognition & 0.83 & 0.62 \\
Quality Work & 0.80 & 0.58 \\
Meaningful Work & 0.70 & 0.49 \\
Influence & 0.84 & 0.63 \\
Authenticity & 0.71 & 0.45 \\
Personal Life & 0.87 & 0.68 \\
Growth and Develop- & 0.89 & 0.72 \\
ment & & 0.67 \\
Satisfaction & 0.86 & \\
\hline
\end{tabular}

Keterangan: Semua konstruk adalah reliabel

pengujian reliabilitas konstruk. Baik tidaknya reliabilitas suatu konstruk dapat dilihat dari nilai construct reliability (CR) dan nilai average variance extracted (AVE). Koefisien reliabilitas konstruk menekankan pada seberapa jauh indikator ukur merefleksikan faktor laten yang disusun. Semakin besar indikator merefleksikan faktor latennya, maka semakin besar nilai reliabilitas pengukuran. Nilai CR 0,70 atau lebih menunjukkan reliabilitas yang baik, sedangkan reliabilitas 0,60-0,70 masih dapat diterima dengan syarat validitas indikator dalam model baik (Hair et al., 2014). Nilai average variance extracted (AVE) juga digunakan untuk menguji reliabilitas. AVE menunjukkan total varians suatu konstruk yang dapat dijelaskan oleh pengukuran yang dilakukan. AVE dihitung sebagai total kuadrat standardized factor loading (squared multiple correlation) dibagi dengan total kuadrat standardizes loading ditambah total varians dari error. Nilai AVE sama dengan atau diatas 0,50 menunjukkan adanya konvergen yang baik (Ghozali, 2017). Nilai AVE harus dihitung untuk setiap konstruk laten. Hasil uji CR dan AVE dapat dicermati pada tabel dibawah ini. Hasil uji menunjukkan nilai CR lebih besar dari 0,60 , nilai $C R$ lebih besar dari 0,60 ini menandakan konstruk tersebut dinyatakan reliabel. Nilai AVE sebagian kecil kurang dari ambang batas 0,50 hal ini menunjukkan bahwa reliabilitas setiap konstruk dengan nilai kurang 0.50 kurang baik, namun jika nilai AVE kurang 0.50 masih dapat diterima dengan syarat nilai CR lebih tinggi dari 0.60 dan validitas konvergen memenuhi syarat.

\section{Kesimpulan}

Berdasarkan analisa data di atas menunjukkan bahwa SCSI memenuhi kriteria fit berdasarkan ukuran goodness of fit dan memenuhi syarat validitas konvergen. Dengan demikian skala SCSI versi Bahasa Indonesia dengan 24 pernyataaan ini memiliki properti psikometri yang memuaskan, andal dan valid sehingga dapat digunakan untuk mengukur kesuksesan karier subjektif. Skala yang sudah diadaptasi dapat dilihat pada Appendix 2.

\section{Referensi}

Abele, A. E., \& Spurk, D. (2009). The longitudinal impact of self-efficacy and career goals on objective and subjective career success. Journal of Vocational Behavior, 74(1), 53-62. https://doi.org/10.1016/j.jvb.2008.10.005 


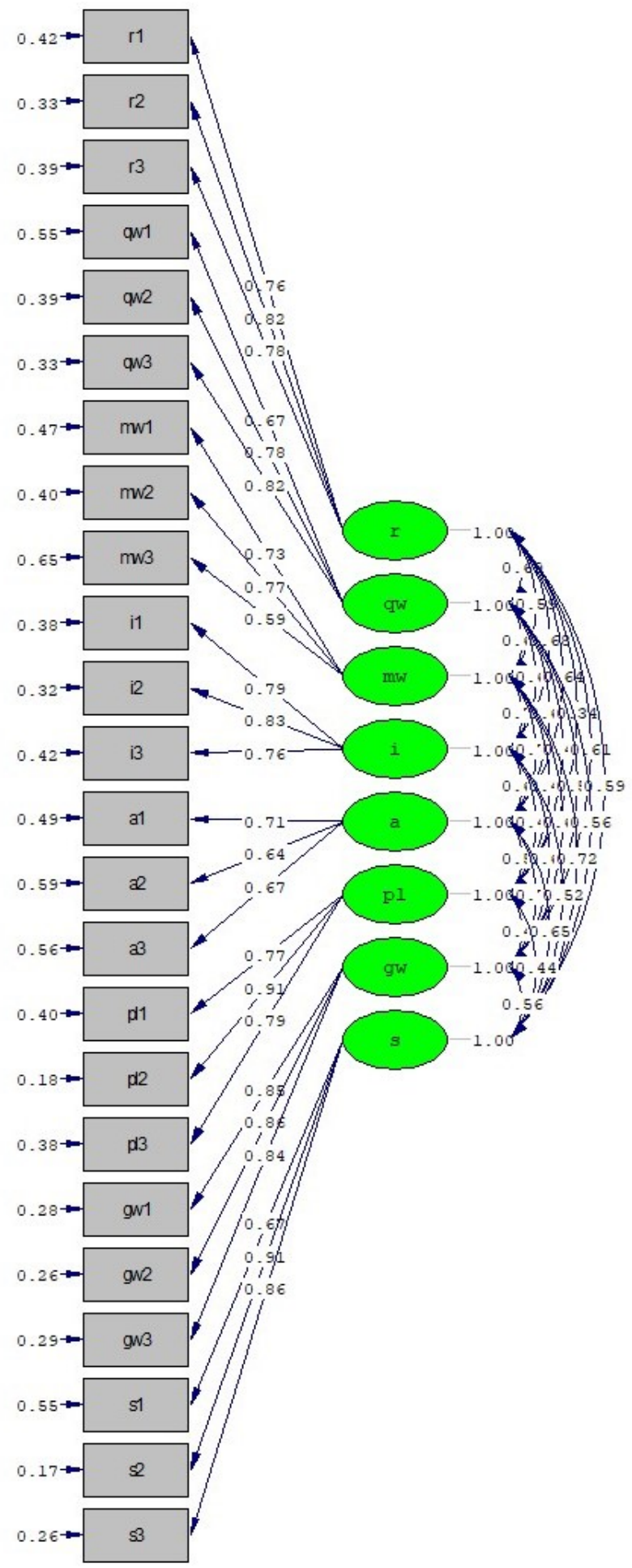

Gambar 1. Chi-Square $=458.84, d f=224, P$-value $=0.00000$, RMSEA $=0.060$

Akbulut, A. Y. (2016). Majoring in information systems: An examination of role model influence. Journal of Educational Computing Research, 54(5), 660-679. https://doi.org/10. 1016/j.chb.2015.11.002

Akkermans, J. \& Kubasch, S. (2017). Trending topics in careers: A review and future research agenda. Career Development
International, 22(6), 586-627. https://doi.org/10.1108/CDI08-2017-0143.

Dries, N., Pepermans, R., \& Carlier, O. (2008). Career success: Constructing a multidimensional model. Journal of Vocational Behavior, 73(2), 254-267. https://doi.org/10. 1016/j.jvb.2008.05.005

Dries, N., Pepermans, R., Hofmans, J., \& Rypens, L. (2009). Development and validation of an objective intraorganizational career success measure for managers. Journal of Organizational Behavior, 30, 543-560. https://doi.org/10. 1002/job.564

Ferdinand, A. (2014). Metode Penelitian Manajemen (5th ed.). Semarang: Seri Pustaka

Fornell, C., \& Larcker, D. F. (1981). Evaluating structural equation models with unobservable variables and measurement error. Journal of Marketing Research, 18(1), 39-50. https: //doi.org/10.2307/3151312

Ghozali, I. (2017). Model Persamaan Struktural Konsep Dan Aplikasi Dengan Program AMOS 24. Semarang: Badan Penerbit Universitas Diponegoro.

Greenhaus, J. H., Parasuraman, S., \& Wormley, W. M. (1990). Effects of race on organizational experiences, job performance evaluations, and career outcomes. Academy of Management Journal, 33(1), 64-86. https://doi.org/10.2307/ 256352

Gunz, H. P., \& Heslin, P. A. (2005). Reconceptualizing career success. Journal of Organizational Behavior, 26, 105- 111. https://doi.org/10.1002/job.300

Hair, J.F., Black, W.C., Babin, B.J. \& Anderson, R.E. (2014) Multivariate Data Analysis. 7th Edition. Upper Saddle River: Pearson Education.

Heslin, P. A. (2003). Self- and other-referent criteria of career success. Journal of Career Assessment, 11(3), 262-286. https://doi.org/10.1177/1069072703254500

Hofmans, J., Dries, N., \& Pepermans, R. (2008). The career satisfaction scale: Response bias among men and women. Journal of Vocational Behavior, 73(3), 397-403. https://doi. org/10.1016/j.jvb.2008.08.001

Huang, C.C., Wang, Y.M., Tsin-Wei Wu, T.W., \& Wang, P.A. (2013). An empirical analysis of the antecedents and performance consequences of using the moodle platform. International Journal of Information and Education Technology, 3(2), 217- 221. https://doi.org/10.7763/IJIET.2013.V3.267

Ingarianti, T.M., Suhariadi, F., \& Fajrianthi F. (2021). Exploring subjective career success. Social Science, Education and Humanities Research, 530, 190-194. https://doi.org/10.2991/ assehr.k.210423.027

International Test Commission. (2016). The ITC Guidelines for the Translating and Adapting Tests (2nd ed.). www.InTestCom.org

Judge, T.A., Cable, D.M., Boudreau, J.W., \& Bretz Jr., R.D.B. (1995). An empirical investigation of the predictors of executive career success. Personnel Psychology, 48, 485-519. https://doi.org/10.1111/j.1744-6570.1995.tb01767.x 
Ng, T. W., Eby, L. T., Sorensen, K. L., \& Feldman, D. C. (2005). Predictors of objective and subjective career success: A meta-analysis. Personnel Psychology, 58, 367-408. https: //doi.org/10.1111/j.1744-6570.2005.00515.x

Ng, T. \& Feldman, D. (2010). T). The relationships of age with job attitudes a meta- analysis. Personnel Psychology, 63, 677-718. https://doi.org/10.1111/j.1744-6570.2010.01184.x

Pan, J., \& Zhou, W. (2015). How do employees construe their career success: An improved measure of subjective career success. International Journal of Selection and Assessment, 23(1), 45-58. https://doi.org/10.1111/ijsa.12094

Polit, D.F., Beck, C.T. \& Owen, S.V. (2007) Is the cvi an acceptable indicator of content validity? Appraisal and recommendations. Research in Nursing \& Health, 30, 459467. https://doi.org/10.1002/nur.20199

Perugini, M., \& Bagozzi, R. P. (2001). The role of desires and anticipated emotions in goal-directed behaviours: Broadening and deepening the theory of planned behaviour. British Journal of Social Psychology, 40(1), 79-98. https: //doi.org/10.1348/014466601164704

Seibert, S. E., Kraimer, M. L., Holtom, B. C., \& Pierotti, A. J. (2013). Even the best laid plans sometimes go askew: Career self-management processes, career shocks, and the decision to pursue graduate education. Journal of Applied Psychology, 98(1), 169- 182. https://doi.org/10.1037/a0030882

Seibert, S. E., Kraimer, M. L., \& Liden, R. C. (2001). A social capital theory of career success. Academy of Management Journal, 44(2), 219-237. https://doi.org/10.2307/3069452

Shockley, K. M., Ureksoy, H., Rodopman, O. B., Poteat, L. F., \& Dullaghan, T. R. (2016). Development of a new scale to measure subjective career success: A mixed-methods study. Journal of Organizational Behavior, 37: 128-153. https://doi. org/10.1002/job.2046
Sperber, A. D. (2004). Translation and validation of study instruments for cross-cultural research. Gastroenterology, 126, 124-128. https://doi.org/10.1053/j.gastro.2003.10.016

Spurk, D., Hirschi, A., \& Dries, N. (2019). Antecedents and outcomes of objective versus subjective career success: Competing perspectives and future directions. Journal of Management, 45(1), 35-69. https://doi.org/10.1177/ 0149206318786563

Turban, D. B., \& Dougherty, T. W. (1994). Role of protégé personality in receipt of mentoring and career success. Academy of Management Journal, 37(3), 688-702. https: //doi.org/10.2307/256706

Zhou, W., Sun, J., Guan, Y., Li, Y., \& Pan, J. (2013). Criteria of career success among Chinese employees: Developing a multidimensional scale with qualitative and quantitative approaches. Journal of Career Assessment, 21(2), 265-277. https://doi.org/10.1177/1069072712471302 


\section{Appendix 1 \\ Subjective Career Success Inventory}

This questionnaire includes statement about your line of work or career field in which you are currently employed. All responses are treated confidentially, in no instance will an individual be identified as having provided a particular response. Place the number of the response on the line at the left of the statement.

1 Strongly Disagree; 2 Disagree; 3 Uncertain; 4 Agree; 5 Strongly Agree

\section{Recognition}

.... my supervisors have told me I do a good job.

.... the organizations I worked for have recognized me as a good performer.

..... I have been recognized for my contributions.

\section{Quality Work}

.... I am proud of the quality of the work I have produced.

.... I have met the highest standards of quality in my work.

.... I have been known for the high quality of my work.

\section{Meaningful Work}

.... I think my work has been meaningful.

..... I believe my work has made a difference.

.... the work I have done has contributed to society.

\section{Influence}

.... decisions that I have made have impacted my organization.
.... the organizations I have worked for have considered my opinion regarding important issues.

.... others have taken my advice into account when making important decisions.

\section{Authenticity}

.... I have been able to pursue work that meets my personal needs and preferences.

..... I have felt as though I am in charge of my own career.

.... I have chosen my own career path

\section{Personal Life}

..... I have been able to spend the amount of time I want with my friends and family.

.... I have been able to have a satisfying life outside of work.

.... I have been able to be a good employee while maintaining quality non-work relationships.

\section{Growth and Development}

..... I have expanded my skill sets to perform better.

..... I have stayed current with changes in my field

..... I have continuously improved by developing my skill set.

\section{Satisfaction}

..... my career is personally satisfying.

..... I am enthusiastic about my career.

..... I have found my career quite interesting. set. 


\section{Appendix 2}

\section{Subjective Career Success Inventory}

Di bawah ini adalah pernyataan yang mungkin menggambarkan karir Anda secara keseluruhan. Semua tanggapan akan diperlakukan secara rahasia. Tuliskan nomor jawaban pada baris di sebelah kiri pernyataan.

Adapun pilihan jawaban yang tersedia adalah: 1 Sangat Tidak Setuju; 2 Tidak Setuju; 3 Tidak Yakin/Ragu-ragu; 4 Setuju; 5 Sangat Setuju

\section{Recognition}

.... Atasan saya mengatakan bahwa saya melakukan pekerjaan dengan optimal.

.... Organisasi tempat saya bekerja mengakui bahwa saya adalah karyawan dengan kinerja yang baik.

.... Selama ini, saya mendapat pengakuan atas kontribusi-kontribusi saya.

\section{Quality Work}

.... Saya bangga atas kualitas kerja yang saya hasilkan.

.... Saya telah memenuhi standard kualitas tertinggi dalam pekerjaan saya.

.... Saya dikenal atas kualitas pekerjaan saya yang tinggi

\section{Meaningful Work}

.... Saya rasa pekerjaan saya bermakna.

.... Saya yakin pekerjaan saya membawa perubahan bagi organisasi.

.... Pekerjaan yang saya lakukan telah memberikan sumbangsih pada masyarakat.

\section{Influence}

.... Keputusan-keputusan yang saya buat telah memberi dampak pada organisasi saya.

.... Pendapat saya terkait dengan isu penting selalu menjadi pertimbangan bagi organisasi.

.... Orang lain/ rekan kerja mempertimbangkan saran saya ketika membuat keputusan penting.

\section{Authenticity}

.... Saya mampu mencari pekerjaan yang memenuhi kebutuhan dan preferensi pribadi saya.

.... Saya merasa bertanggung jawab atas karier saya sendiri.

.... Saya telah memilih jalur karier saya sendiri.

\section{Personal Life}

.... Selama ini, saya dapat menghabiskan sejumlah waktu yang saya mau bersama teman dan keluarga.

.... Selama ini, saya dapat memiliki kehidupan yang memuaskan di luar pekerjaan.

.... Selama ini, saya dapat menjadi karyawan yang baik sembari tetap mempertahankan hubungan yang berkualitas di luar pekerjaan.

\section{Growth and Development}

.... Saya telah mengembangkan ketrampilan agar dapat bekerja lebih baik.

.... Saya terus mengikuti perkembangan di bidang saya.

.... Saya terus meningkatkan diri dengan mengembangkan rangkaian keterampilan saya.

\section{Satisfaction}

..... Karier saya memuaskan secara personal.

.... Saya antusias terhadap karier saya.

.... Saya merasa karier saya sangat menarik. 